\title{
UKLAD TWARZY I GESTOSFERY W KONTEKŚCIE KONFLIKTU KOMUNIKACYJNEGO W KOMUNIKACJI BEZPOŚREDNIEJ
}

JOANNA PUPPEL Dowolny uktad fizyczny, który zachowuje się
nieokresowo, jest nieprzewidywalny

Edward Lorenz

\section{Wprowadzenie}

Twarz ludzka wraz z towarzyszącą jej gestosferą jest istotnym elementem codziennej niszy komunikacyjnej ${ }^{1}$ wykorzystywanej w międzyosobowej komunikacji bezpośredniej (Puppel, S. 2008, 2011). Towarzysząc przekazom werbalnym tworzą one swoisty i niepowtarzalny układ fizyczny o charakterze komunikacyjnym. Stąd też interesującym wydaje się spojrzenie na złożoność systemu komunikacji niewerbalnej, jakim jest układ twarzy i gestosfery (UTG) z perspektywy ludzkiego działania/performatywności. W niniejszym artykule zakładam, że układ twarzy i gestosfery posiada najsilniejszy indeks performatywności (zob. Puppel 2013) w komunikacji bezpośredniej. Celem przeprowadzenia postępowania potwierdzającego słuszność powyższego założenia stawiam hipotezę główną o następującej treści: UTG odgrywa istotną rolę komunikacyjną w konfliktach w komunikacji bezpośredniej.

\footnotetext{
${ }^{1}$ Nisza komunikacji codziennej (ang. daily routine communicative niche) - poziom komunikacji, który składa się z najszerszych możliwych językowych zasobów i kontekstów językowego i niejęzykowego użycia (za Puppel, S. 2011: 111).
} 
Hipotezę tę rozbito na trzy podhipotezy, a mianowicie:

a) tylko wyraz twarzy jest odbierany jako konfliktowy w tzw. 'zanurzeniu gesturalnym' gdzie twarz dominuje w relacji 'twarz - gest' w generowaniu konfliktu,

b) wyraz twarzy i towarzyszący mu gest odbierane są wspólnie jako konfliktowe (tj. twarz i gest są równo konfliktogenne w relacji 'twarz - gest'),

c) tylko gest odbierany jest jako konfliktowy w obecności twarzy nacechowanej bądź pozytywnie bądź neutralnie, gdzie gest dominuje w relacji 'twarz - gest' w generowaniu konfliktu.

Materiałem badawczym dla potwierdzenia niniejszych hipotez jest kwestionariusz ankietowy, omówiony w dalszej części artykułu. Został on przeprowadzony anonimowo wśród respondentów należących do społeczności akademickiej.

\section{Indeks performatywności}

Zakłada się, że działanie, czyli performance, jest formą przekazu, wykonaną przed publicznością bądź wyrażoną wraz z publicznością. Według Goffmana (1956/2000) performance to najogólniej rozumiana interakcja twarzą w twarz, podczas której ludzie wywierają na siebie wzajemny wpływ. Natomiast interakcja jest rozumiana jako cały interakcyjny proces zachodzący przy każdym akcie komunikacyjnym. I tak, Goffman definiuje pojęcie performance: „,...) jako wszelką działalność danego uczestnika interakcji w danej sytuacji służącą wpływaniu w jakikolwiek sposób na któregokolwiek z innych jej uczestników" (Goffman, 2000: 45 - tłum. H. Datner-Śpiewak i P. Śpiewak).

Warto jednak dodać, że zanim pojęcie powyższe zadomowiło się na dobre w badaniach socjologiczno-antropologicznych, pojawiło się ono w kontekście nauk filozoficzno-językoznawczych wraz z klasycznym dziełem Austina pt. How to do things with words (1962). Według Austina $(1962,1970)$ angielski czasownik ,to perform” występuje zazwyczaj z rzeczownikiem oznaczającym czynność. Nazwa ta wskazuje, iż wygłoszenie wypowiedzi jest równoznaczne z wykonaniem jakiejś czynności, o czym nie myśli się normalnie a tylko o wypowiedzeniu czegoś. Chodzi tu oczywiście o sprawczą funkcję komunikacji, tkwiące w niej moce przyczynowe i o możliwość działania za pomocą zasobów językowych jak również niejęzykowych.

Mając na względzie zaproponowaną przez Lorenza teorię chaosu deterministycznego (Lorenz 1969, 1972) i przyglądając się tzw. 'efektowi motyla' (ang. butterfly effect), który to efekt dopuszcza możliwość, iż gwałtowny huragan może być skutkiem trzepotania skrzydeł motyla w miejscu odległym o tysiące kilometrów od tego zdarzenia, wolno przypuszczać, iż uśmiech wywoła stan harmonii w ludzkiej interakcji, natomiast twarz w grymasie, czy też wykonanie 
negatywnego gestu skutkować będzie niszczycielskim 'tornadem' w postaci powstania konfliktu międzyosobowego. Możemy więc śmiało powiedzieć, iż ludzkie ciało w swojej niewerbalnej performatywności zarządza całym układem twarzy i gestosfery. Również w kontekście konfliktu możemy powiedzieć, iż UTG jako całość bierze aktywny udział w procesie komunikacyjnym.

W teorii i praktyce komunikacji niewerbalnej można pokusić się o stworzenie performatywnej topografii UTG, którą można podzielić w następujący sposób:

- performatywna topografia ludzkiej twarzy (T),

- performatywna topografia ludzkiej gestosfery $(G)$,

- performatywna topografia całego układu twarzy i gestosfery (UTG).

Wymienione powyżej performatywne topografie posiadają różny stopień siły, bądź demonstrują różny potencjał dla wyrażenia różnego natężenia emocji w danym akcie komunikacyjnym, również w konflikcie komunikacyjnym. Jednak zaznaczyć trzeba, że przeprowadzone wcześniej pilotażowe badanie na temat indeksu performatywności (zob. Puppel 2013) wykazało, iż to performatywna topografia całego układu twarzy i gestosfery jest uważana za najbardziej optymalny, najsilniejszy i tym samym najskuteczniejszy układ niewerbalny (twarz-gestosfera) w akcie komunikacyjnym, w tym w akcie o charakterze konfliktu. UTG reprezentuje rysunek poniżej:

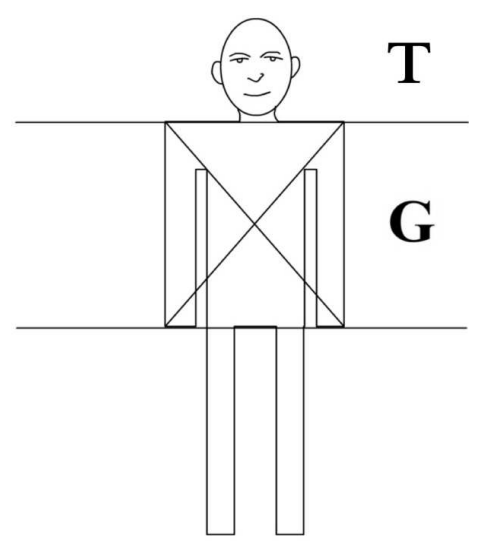

Rys. 1. Układ twarzy i gestosfery (UTG) (zob. Puppel 2013)

\section{Konflikt komunikacyjny}

Konflikt jest niejako endemiczny dla wszystkich istot społecznych. Jest on nieuniknionym elementem życia. Ze względu na swą wszechobecną i perswazyjną naturę samo pojęcie 'konfliktu' nabyło wiele znaczeń i konotacji, które 
ukazały prawdziwe semantyczne rozchwianie. Opierając się na definicji endemiczności w szerokim tego słowa znaczeniu sugeruje się, iż konflikt odnosi się do różnego typu antagonistycznych interakcji. Bardziej szczegółowo możemy zdefiniować konflikt jako sytuację, w której dwie lub więcej stron prezentują niezgodne cele, a ich poglądy i zachowania są współmierne $\mathrm{z}$ tą niezgodnością (zob. Pondy 1967; Fink 1968).

W komunikologii konflikt rozpatrywany jest z perspektywy użycia zarówno zasobów językowych (werbalnych) jak i niejęzykowych (niewerbalnych). I tak w oparciu o interakcje międzyosobowe konflikt postrzegany jest jako swoisty performance, czyli działanie ludzi wobec innych ludzi w określonej przestrzeni komunikacyjnej, tak by działanie to wywarło na innych określony wpływ. Oczywiście w przypadku konfliktu wywarcie wpływu jest o charakterze negatywnym, czyli że jest on rozpatrywany jako nieporozumienie, bądź też jako nieczytelność przekazu.

W komunikacji bezpośredniej o charakterze konfliktowym możemy również mówić o zjawisku natężenia konfliktu komunikacyjnego, które na skali może oscylować od najłagodniejszego do najbardziej ekstremalnego. Jest to stopień emocjonalnego zaangażowania $\mathrm{w}$ dążeniu do konfliktu, a więc natężenie to wynika, np. zdaniem Cosera (1956/2009), z rodzaju stosunków wiążących zantagonizowane strony; im te relacje są bardziej osobiste i pierwotne, tym konflikt jest o wyższym natężeniu. Natomiast według Dahrendorf'a (1959) natężenie konfliktu to stopień wydatkowania energii i uwikłania stron w konflikcie. Im większą wagę przypisuje poszczególny uczestnik do kwestii związanych z konfliktem i do jego istoty, tym większe natężenie ma dany konflikt. Można ogólnie powiedzieć, że konflikt ma wysokie natężenie wtedy, gdy koszt zwycięstwa lub przegranej jest dla zaangażowanych stron wysoki (np. stopień niezadowolenia).

W komunikacji twarzą w twarz najistotniejszą rolę odgrywa układ twarzy i gestosfery w wywoływaniu odpowiednich reakcji od stanu konfliktu poprzez stan neutralny, aż do stanu harmonii (zadowolenia, szczęścia). Wyrazistość tego w UTG jest istotnym czynnikiem w komunikacji o charakterze konfliktowym bądź konfliktogennym.

\section{Omówienie ankiet}

W badaniu przeprowadzonym dla niniejszego projektu udział wzięło 153 studentów Wydziału Neofilologii UAM oraz Wydziału Filologii Polskiej i Klasycznej UAM. Zadaniem respondentów było przyjrzenie się trzem zdjęciom obrazującym trzy różne układy twarzy i gestosfery i udzielenie odpowiedzi na dwa pytania towarzyszące tym trzem zdjęciom. Zdjęcia te przedstawiają następujące konfiguracje UTG: 
Zdjęcie nr 1 - Wyraz twarzy nacechowany jest negatywnie (twarz wyraża złość), natomiast gestosfera wzmacnia ten negatywny akt komunikacyjny.

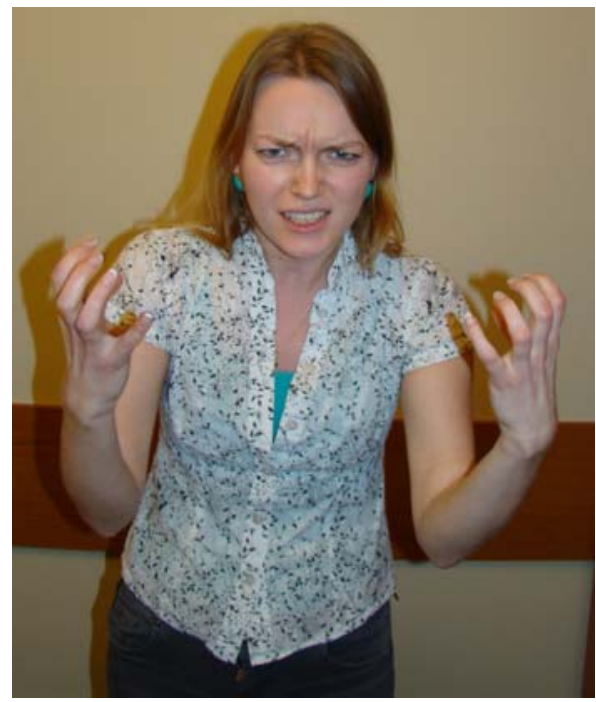

Zdjęcie nr 1

Zdjęcie nr 2 - Wyraz twarzy nacechowany jest pozytywnie (twarz wyraża radość), natomiast gestosfera nacechowana jest 'neutralnie'.

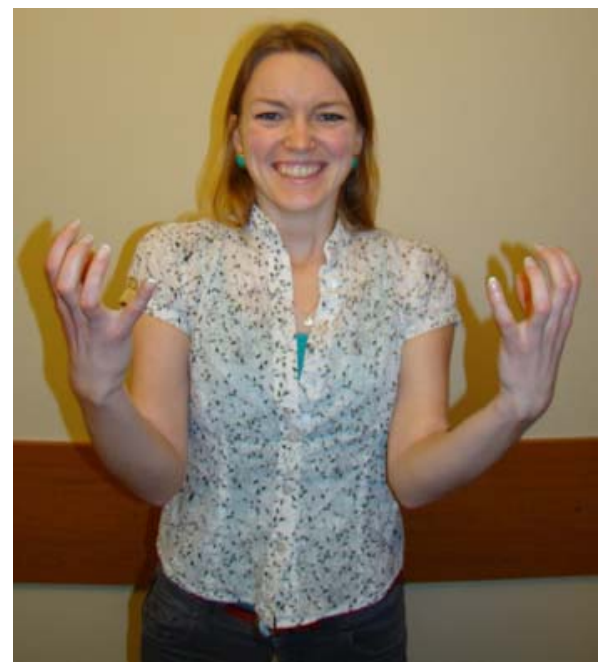

Zdjęcie nr 2 
Zdjęcie nr 3 - Wyraz twarzy nacechowany jest pozytywnie (twarz wyraża radość), natomiast gestosfera wyrażona jest w sposób emblematyczny (gest przedstawia tzw. 'gest Kozakiewicza').

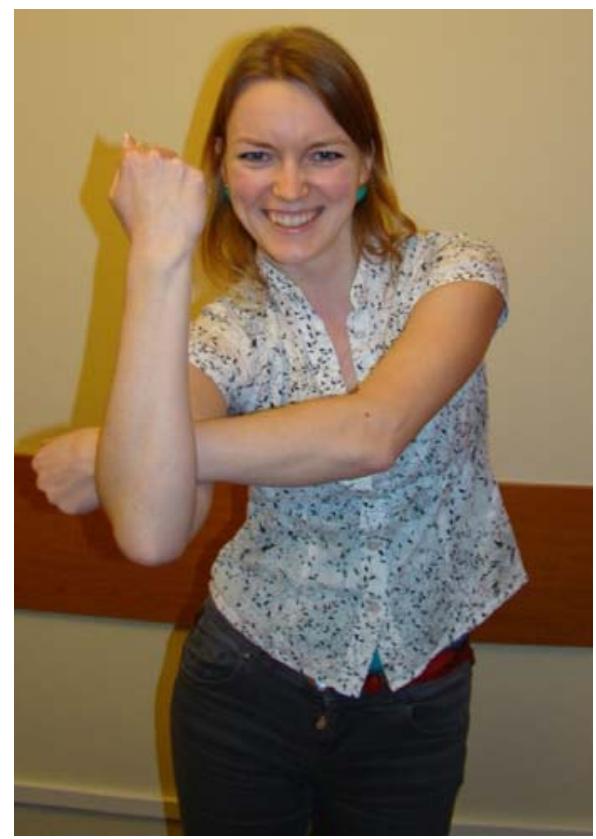

Zdjęcie nr 3

Zdjęciom towarzyszyły następujące pytania ankietowe: Pytanie ankietowe A1. Czy Pana/Pani zdaniem układ 'twarz-gest' przedstawiony na zdjęciu nr 1 może generować konflikt? Proszę zakreślić swoją odpowiedź.

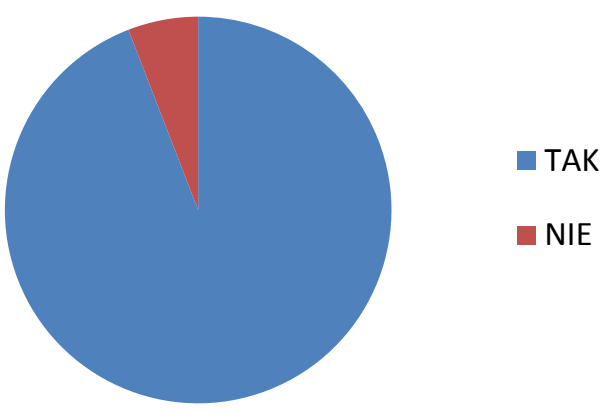

Wykres 1. Pytanie ankietowe A1 
Wynik: Na Pytanie ankietowe A1 94,1\% respondentów odpowiedziało 'Tak', a 5,9\% 'NIE'.

Pytanie ankietowe A2. Jeśli TAK, to który/e element/y układu 'twarz-gest' przedstawionego na zdjęciu nr 1 jest/są Pana/Pani zdaniem konfliktogenny/e? Proszę zakreślić swoją odpowiedź.

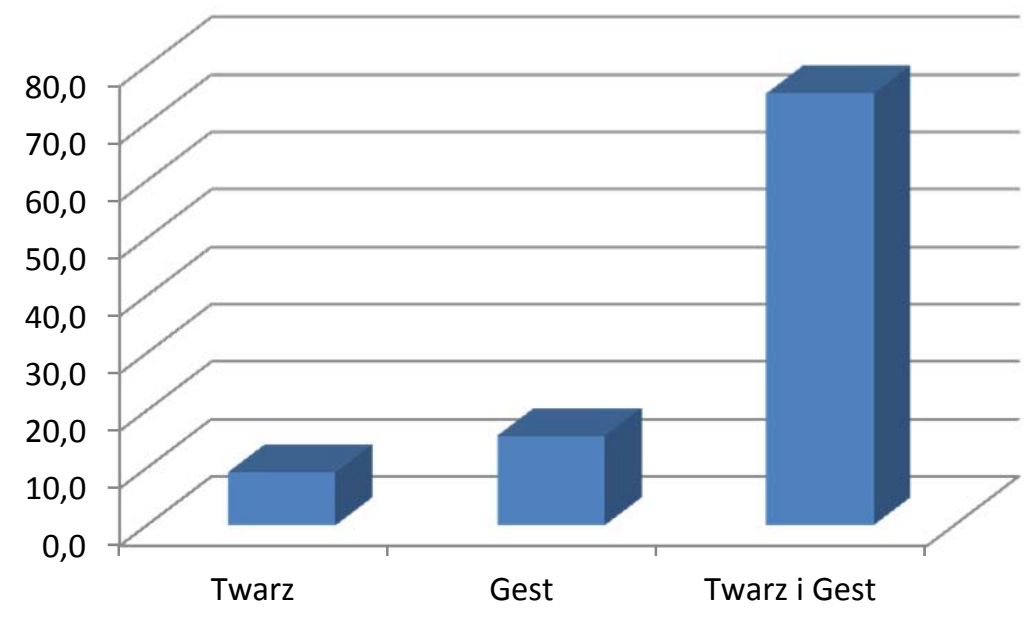

Wykres nr 2. Pytanie ankietowe A2

Wynik: W odpowiedzi na Pytanie ankietowe A2 9,2\% respondentów zaznaczyło 'twarz' jako element konfliktogenny, 15,6\% respondentów zaznaczyło 'gest', a 75,2\% ankietowanych zaznaczyło układ 'twarz i gest' jako element najbardziej konfliktogenny w zaprezentowanym układzie komunikacyjnym (patrz Zdjęcie nr 1).

W części otwartej załączonej do pytania ankietowego A2 pojawiły się również komentarze, które warto tutaj przytoczyć. Najczęściej pojawiały się następujące uwagi:

- „połączenie wyrazu twarzy, gestu i nachylenia ciała w stronę patrzącego”.

- ,pochylenie ciała do przodu w kierunku rozmówcy, zgarbienie się, wysunięcie głowy do przodu".

- ,postawa ciała”.

Pytanie ankietowe B1. Czy Pana/Pani zdaniem układ 'twarz-gest' przedstawiony na zdjęciu nr 1 może generować konflikt? Proszę zakreślić swoją odpowiedź.

Wynik: 23,7\% respondentów odpowiedziało 'TAK' odnośnie Pytania ankietowego B1, natomiast 76,3\% respondentów odpowiedziało 'NIE'. 


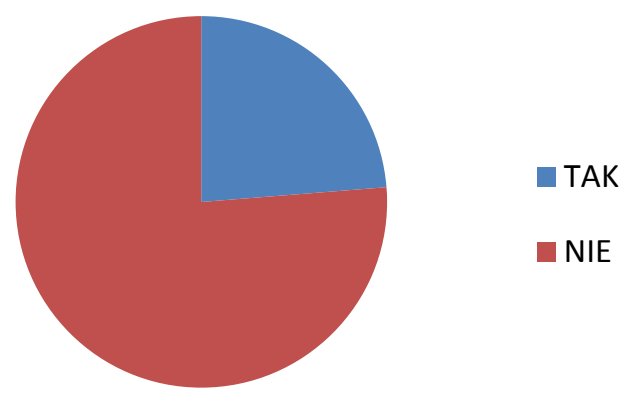

Wykres nr 3. Pytanie ankietowe B1

Pytanie ankietowe B2. Jeśli TAK, to który/e element/y układu 'twarz-gest' przedstawionego na zdjęciu nr 1 jest/są Pana/Pani zdaniem konfliktogenny/e? Proszę zakreślić swoją odpowiedź.

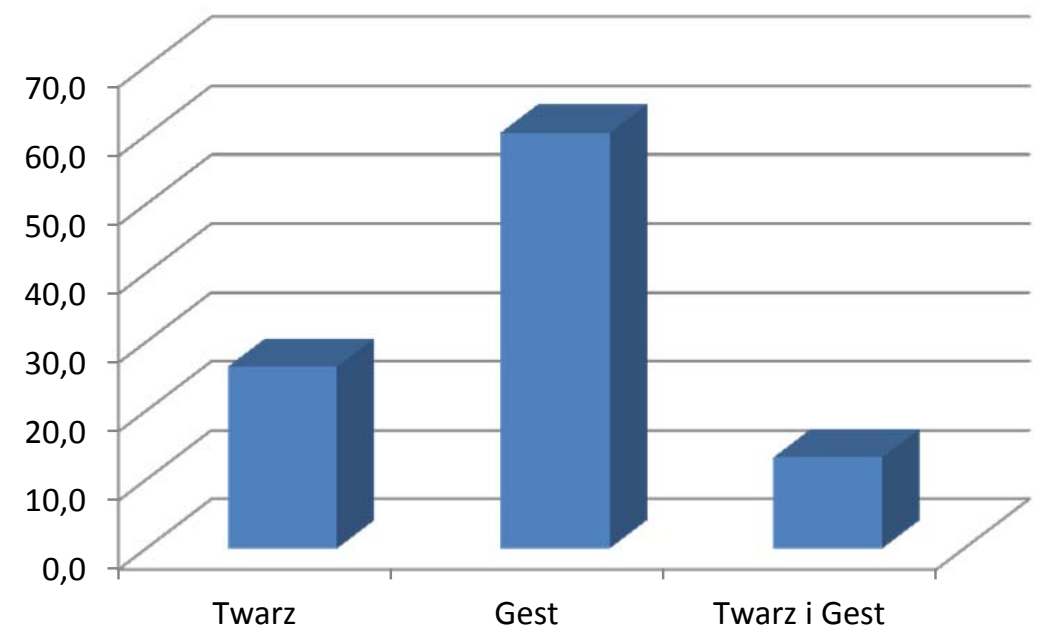

Wykres nr 4. Pytanie ankietowe B2

Wynik: 23,7\% respondentów odpowiedziało 'TAK' odnośnie Pytania ankietowego B1, natomiast $76,3 \%$ respondentów odpowiedziało 'NIE'.

Przedstawione powyżej wyniki wskazują, że najbardziej konfliktogennym elementem układu komunikacyjnego przedstawionego na Zdjęciu nr 2 okazuje się 'Gest'; aż 60,4\% respondentów wskazało na konfliktogenny charakter tego elementu. 'Twarz' została oceniona na $26,4 \%$, natomiast na układ 'Twarz i gest' jako konfliktogenny wskazało tylko $13,2 \%$ ankietowanych. 
Pytanie ankietowe C1. Czy Pana/Pani zdaniem układ 'twarz-gest' przedstawiony na zdjęciu nr 1 może generować konflikt? Proszę zakreślić swoją odpowiedź.

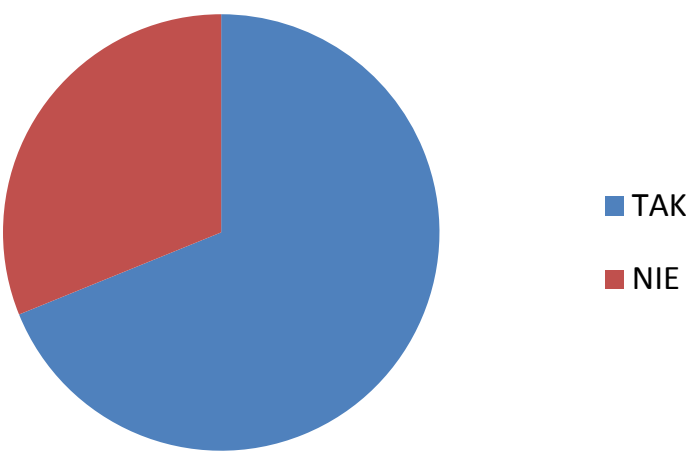

Wykres nr 5. Pytanie ankietowe $\mathrm{C} 1$

Wynik: Układ 'twarz-gest' przedstawiony na Zdjęciu nr 3 został przez respondentów uznany w $68,9 \%$ jako konfliktogenny. Natomiast $31,1 \%$ ankietowanych uznało ten układ jako niekonfliktogenny.

Pytanie ankietowe C2. Jeśli TAK, to który/e element/y układu 'twarz-gest' przedstawionego na zdjęciu nr 1 jest/są Pana/Pani zdaniem konfliktogenny/e? Proszę zakreślić swoją odpowiedź.

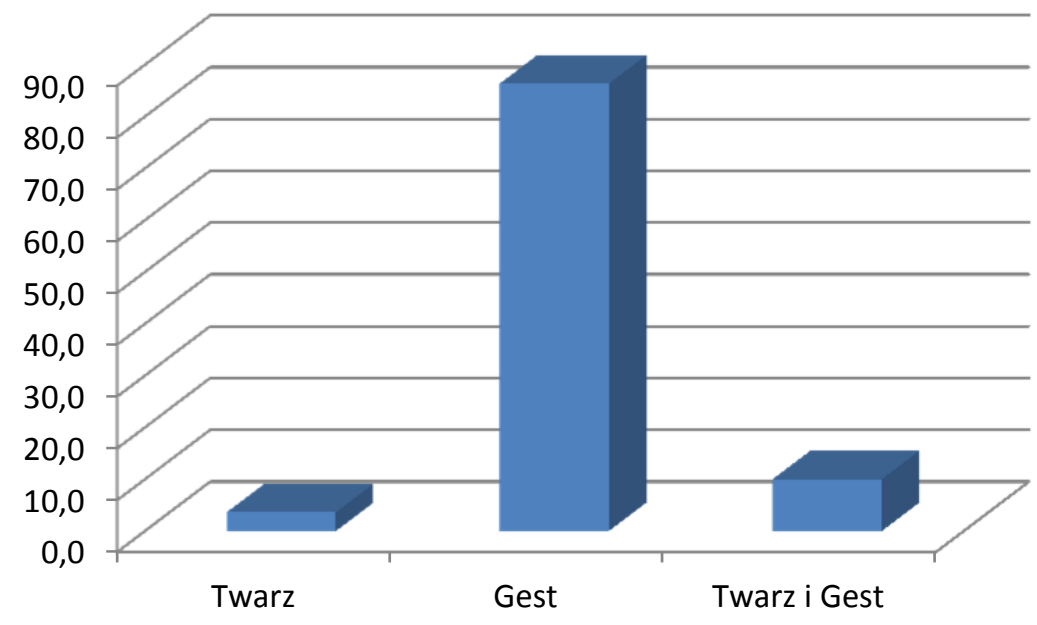

Wykres nr 6. Pytanie ankietowe $\mathrm{C} 2$ 
Wynik: $86,4 \%$ respondentów wskazało na 'gest' jako konfliktogenny w tym układzie komunikacyjnym, natomiast 'twarz' tylko jako 3,6\%, natomiast układ 'twarz i gest' jako w 10\% konfliktogenny.

\section{Wnioski}

Z przeprowadzonej analizy wynika, iż najbardziej konfliktogenny jest układ UTG jako całość, czyli w relacji 'twarz-gest'. Oba te elementy są wspólnie konfliktogenne (patrz Wykres nr 2). Ponadto z otrzymanych wyników można wywnioskować, że również w sytuacji, gdy gest nacechowany jest negatywnie, w obecności twarzy nacechowanej pozytywnie (patrz Zdjęcie nr 3), układ ten (tj. dominacja gestu nad twarzą) odbierany jest jako konfliktogenny. Widać ponadto wyraźnie, iż gest emblematyczny dominuje w relacji 'twarz-gest' (Wykres nr 6). Oznacza to, iż symboliczność gestu ma ogromną siłę komunikacyjną także w wywoływaniu konfliktu komunikacyjnego. Za przykład może również posłużyć bardzo wymowna scena z filmu pt. „Jaś Fasola: nadciąga totalny kataklizm” (1997), gdzie główny bohater, przybierając twarz nacechowaną pozytywnie, jednocześnie wymachuje do przechodniów rękami z wyciągniętymi środkowymi palcami. Ilustruje to poniższy kadr z filmu:

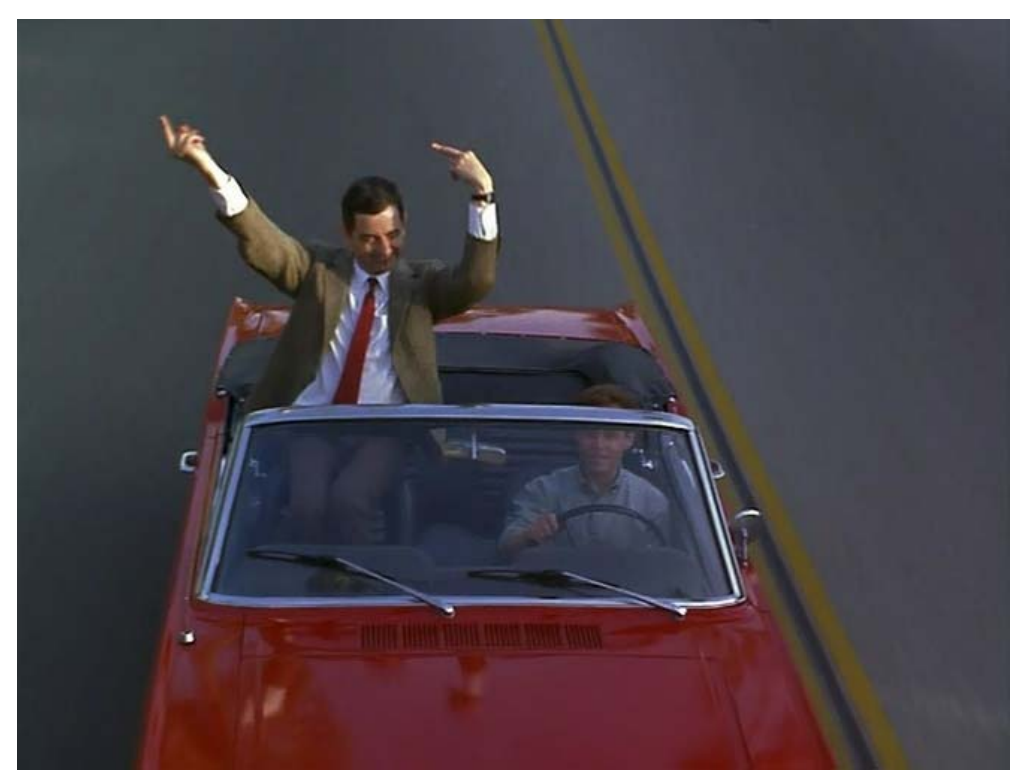

Fot. nr 1. Kadr z filmu „Jaś Fasola: nadciąga totalny kataklizm” (1997) 
Z całą pewnością analiza danych badawczych zebranych za pomocą kwestionariusza ankietowego wykazuje, że układ twarzy i gestosfery (UTG) w tzw. 'zanurzeniu gesturalnym' rzeczywiście odgrywa istotną rolę komunikacyjną w generowaniu konfliktu w komunikacji bezpośredniej.

\section{Bibliografia}

Austin, J.L. 1962. How to do things with words. Oxford: Clarendon Press.

Austin, J.L. 1970. „Performative utterances”. W: Austin, J.L. Philosophical papers. Oxford: Oxford University Press. 233-252.

Coser, L.A. 1956. The functions of social conflict. Glencoe, Il: Free Press.

Coser, L.A. 2009. Funkcje konfliktu społecznego. Kraków: Zakład Wydawniczy NOMOS.

Dahrendorf, R. 1959. Class and class conflict in industrial society. Stanford: Stanford University Press.

Fink, C.F. 1968. „Some conceptual difficulties in the theory of social conflict”. Journal of Conflict Resolution 12. 412-460.

Galtung, J. 1969. „Conflict as a way of life”. W: Freeman, H.L. (red.). Progress in mental health. London: Churchill.

Goffman, E. 2000. Człowiek w teatrze życia codziennego. (tłum. H. Datner-Śpiewak i P. Śpiewak, opracowanie i wstęp J. Szacki). Warszawa: Wydawnictwo KR.

Goffman, E. 1956. The presentation of self in everyday life. London: Allen Lane/The Penguin Press.

Lorenz, E.N. 1969. „Three approaches to atmospheric predictability”. American Meteorological Society 50 (5). 345-351.

Lorenz, E.N. 1972 „Predictability: does the flap of a butterfly’s wings in Brazil set off a tornado in Texas?" Online: http://eaps4.mit.edu/research/Lorenz/Butterfly_1972.pdf (ostatnie wejście 08.02.2014).

Kaus, J. 2012. „Some notes on the nature of conflict”. W: Puppel, S. (red.). Transkomunikacja II. Poznań: Katedra Ekokomunikacji UAM. 51-66.

Pondy, R.L. 1967. „Organizational conflict: concepts and models”. Administrative Science Quarterly 12. 296-320.

Puppel, J. 2011. „Przestrzeń jako kategoria organizacyjna w komunikacji bezpośredniej”. W: Chałacińska, H. i K. Kropaczewski. (red.). W kręgu problemów ekologii kultury. Poznań: Wydawnictwo Naukowe UAM. 123-130.

Puppel, J. 2013. "Facework and gestures: a preliminary analysis of the communicative power of human performative non-verbal practices". Scripta Neophilologica Posnaniensia XIII. 85-90.

Puppel, J. 2014. Rola i obecność gestów rytualnych w przestrzeni publicznej. Analiza rzeźb sakralnych $w$ światyniach katolickich na terenie miasta Poznania $i$ wybranych okolic. Poznań: Wydawnictwo Naukowe UAM.

Puppel, S. 2008. „Communicology: remarks on the reemergence of a paradigm in communication studies”. W: Puppel, S. i M. Bogusławska-Tafelska. (red.). New Pathways in linguistics 2008. Olsztyn: Uniwersytet Warmińsko-Mazurski w Olsztynie. 11-22.

Puppel, S. 2011. „Human communication and communicative skills: a general philosophy and evolving practical guidelines". W: Puppel, S. i M. Bogusławska-Tafelska (red.). New pathways in linguistics 2011. Olsztyn: Uniwersytet Warmińsko-Mazurski w Olsztynie. 107-118. 